\title{
LARGE AND MEDIUM-SIZED TOWNS IN BULGARIA IN REGIONAL DEVELOPMENT AND REGIONAL POLICY
}

\author{
MARGARITA ILIEVA \\ National Institute of Geophysics, Geodesy and Geography \\ Bulgarian Academy of Sciences \\ Sofia 1113 G.Bonchev str. Bl. 3 \\ Institute of Geography \\ Kazimierz Wielki University \\ 85-428 Bydgoszcz 15 Mińska str. \\ Ilieva_mm@abv.bg
}

\begin{abstract}
The implemented regional policy in Bulgaria gives priority to the growing role of the towns, especially the large and medium-sized ones, and of the urban agglomerations in the regional development as well as to the cohesion between regions. The uneven distribution of cities and towns is one of the reasons for differences in the socio-economic development, for disparities between administrative districts, planning regions and primarily for intraregional differences and for the available problem "centre-periphery" (Operative Program..., 2007). Thirty six agglomeration areas are identified in the country, being poles of growth in the national economy. The urban zones of three of these cities are defined as European functional regions - Plovdiv, Varna and Bourgas.
\end{abstract}

Key words: Bulgaria, large town, medium-sized town, regional development, regional policy

There are significant differences between the urban settlements in Bulgaria in terms of their socioeconomic, infrastructural, spatial and cultural-historical development, their number of population ${ }^{1}$, demographic structure, functions, role in regional development and regional policy. The implemented regional policy in Bulgaria gives priority to the growing importance of the towns, especially of the large and medium-sized ones, and of the urban agglomerations in the regional development as well as to the cohesion between regions.

Large and medium-sized towns constitute a small portion of the total number of urban settlements in Bulgaria (In total there were 255 towns in 2010) (Fig. 1). Approximately 180 of them (70 per cent) have less than 10 thousand inhabitants. Most of the cities took shape in the second half of the

1 According to the classification, accepted by Bulgarian experts, the urban settlements are divided into five groups: very big cities (above 400000 people), cities (100 $000-400000)$, medium-sized towns (30000 - 100000$)$, small towns (10 000 -30000 ) and very small towns (up to 10000 people) (Naredba No 5..., 1995). For the purposes of 2011-census, the EU statistic division of the towns by number of population was accepted. Information about the groups of towns with 20000- 24999 and 25000-50000 people makes it difficult to delineate the medium-sized towns In the country (30000-100 000). 
$20^{\text {th }}$ century. The low share of the urban population and the lack of big cities in the country until the mid-20 $0^{\text {th }}$ century indicated a low urbanization level.

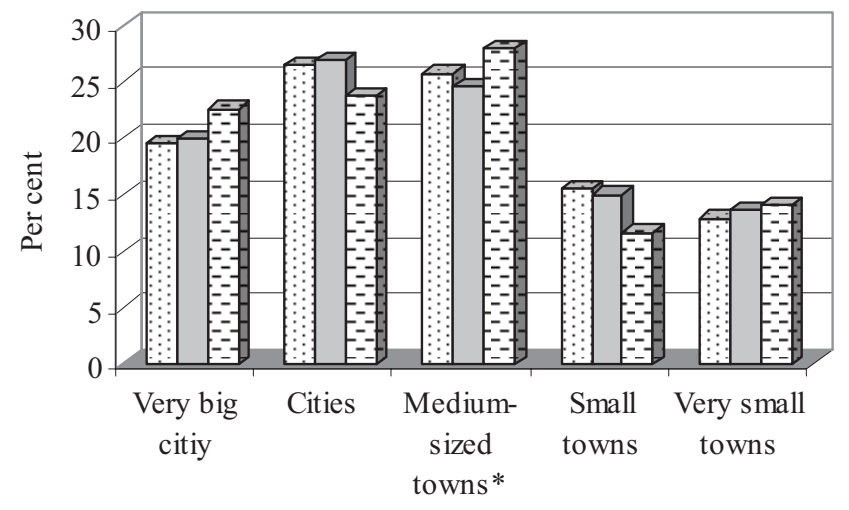

曰1992 2001 曰2011

Fig.1. Structure of Bulgarian urban settlements by size

* medium-sized towns in 2011 of over 25000.

Data source: National Statistical Institute

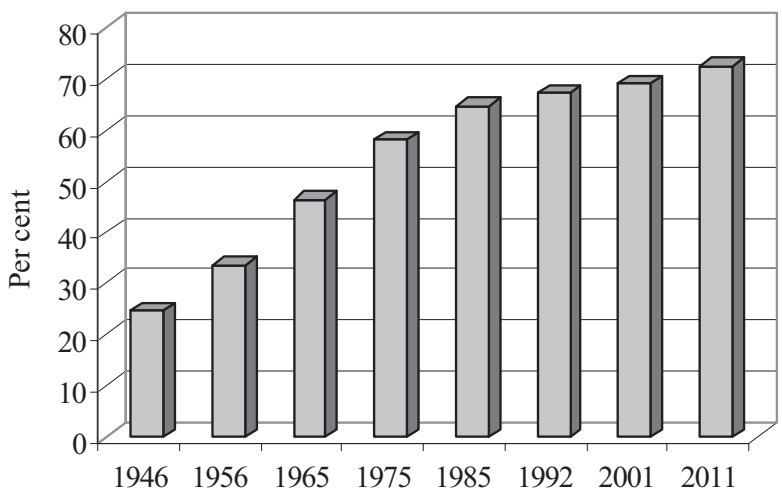

Fig. 2. Share of urban population in Bulgaria by census years (1946-2011)

Data source: National Statistical Institute

In the second half of the 20th century the number of towns and of the urban population significantly increased and as it can be seen from the last census (1.03.2011) 72.5 per cent of the Bulgarian population lives in cities and towns (Fig. 2). a characteristic feature of the urbanization process in Bulgaria, observed in the recent years, is the greater concentration of population in the cities and medium-sized towns. In 2011 more than 45 per cent of Bulgaria's population is concentrated in 29 cities and medium-sized towns of over 50 thousand people, i.e. 74.3 per cent of the urban population. About 33.6 per cent of the country population live in the cities of over 100000 inhabitants such as Sofia, Plovdiv, Varna, Burgas, Ruse, Stara Zagora, Pleven (of them 16.4 per cent live in Sofia). Among the factors, which considerably encourage the migration increase to the large and medium-sized towns, are their bigger attractiveness, the greater expectation of people, better job opportunities, 
successful life and many others. At the same time, the process of sub-urbanization in Bulgaria is weaker as compared to that of the Central European countries in transition.

A pronounced tendency towards a decrease of the urban population in Bulgaria can be observed in the last two decades as a result of the negative demographic processes (negative natural increase, negative migration balance). This is closely related to the continuing drop in the total number of the country's population (Fig. 3).

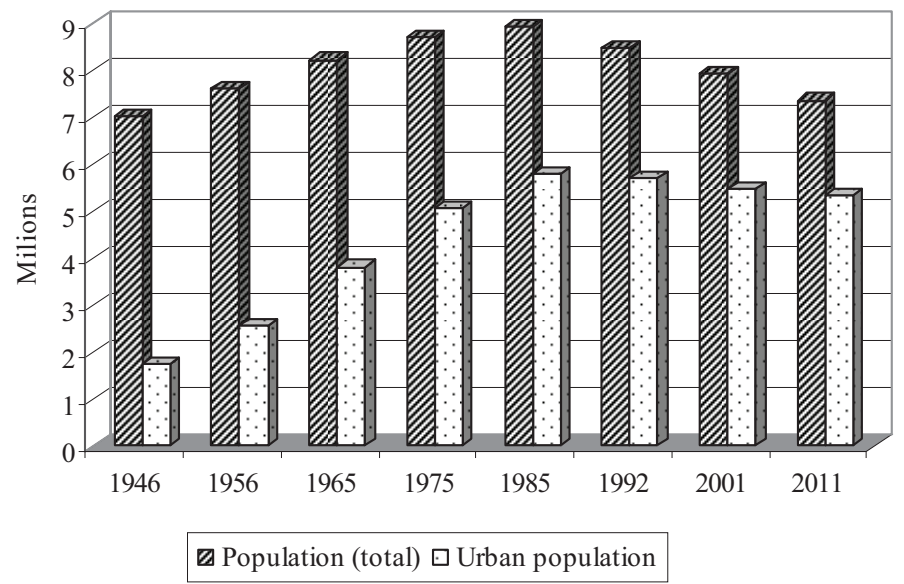

Fig. 3. Number of Bulgaria's Population by census years (1946-2011) Data source: National Statistical Institute

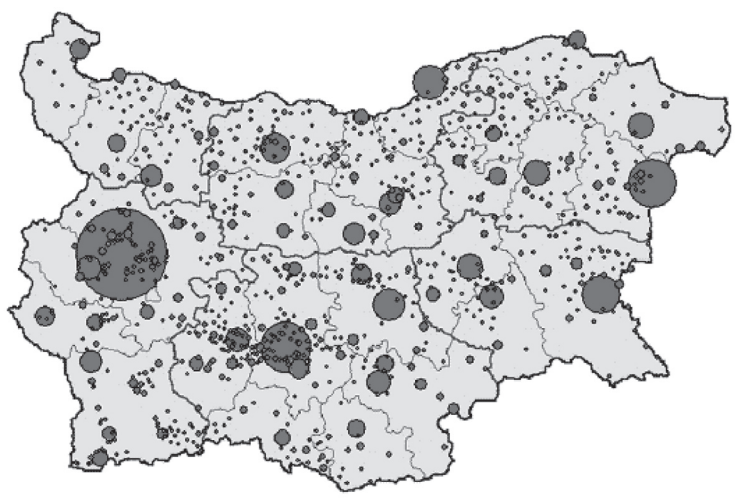

Fig. 4. Territorial Distribution of the Urban Settlements in Bulgaria Source: Operational Program Regional Development

Considerable differences can be observed in the territorial distribution of the urban population on a nationwide scale. There are vast areas, where the urban population has either a very small share or it entirely lacks, e.g. in some peripheral regions, mountain zones, plains and valleys. In the present day picture of the settlement network, the uneven distribution of the large cities stands out clearly against the background of the overall even distribution of the small cities/towns and villages (Fig. 4). Only 5 out of the total 28 districts (NUTS3) have more than one city or medium-sized town (districts with centres Plovdiv, Haskovo, Stara Zagora, Lovech and Veliko Tarnovo). This means uneven distribution 
of the population on the territory, a certain lack of balance of the settlement network in terms of location of the large cities and respectively uneven socio-economic development. As a consequence, vast areas of the national territory remain away from the big urban service centres and give rise to the "centre-periphery" problem. The uneven development of the network of large cities is the cause for the observed disparities in the socio-economic development within the boundaries of the national territory, whose partial expressions are the differences among the planning regions and above all inside the regions (Natsionalna Strategia..., 2005, Operativna Programa..., 2007).

The geographical situation of Bulgaria on the Balkan Peninsula and in South-Eastern Europe is favourable and makes it an important trans-regional centre and a "bridge" between West and East Europe and the Middle East. But Bulgaria has a peripheral location, regarding the metropolises in the European core, and maintains poor connections with these cities. "In most of the peripheral countries and regions, the day return business trips ${ }^{2}$ to foreign cities are simply not possible" (ESPON 2013..., pp. 37). These facts determine the unique location and significance of Sofia capital city as a political, administrative, social, transport and service centre on a national level as well as its place in the European settlement network. "In the 2003 ESPON Project of Nodregio and partners, concerning the network of functioning urbanized areas (FUA) in Europe, the evaluation points out to the existence of one such areal in Bulgaria - a city of European significance (MEGA) (Sofia), three areas - cities of international/national significance (Plovdiv, Varna and Burgas) and 27 areas - cities of regional/local significance. In our estimation the number of 27 is somewhat overestimated and should rather read 12 cities, since quite a number of the medium-size cities, including some district centres, have lost their active organizational role and characteristic of centres of growth" (Nationalna Strategia..., 2005). By 2004 ESPON the metropolitan agglomeration of Sofia capital city is assigned to the lowest 4th category (MEGAs typology), while the urban zones of Plovdiv, Varna and Burgas are defined as European functional regions (Operativna Programa..., 2007). According to Nordregio ESPON TeDi, 2009 , functional urban areas of different categories have been defined - for example, Sofia (under the category 1-5 million inhabitants), Plovdiv and Varna (250 $000-1000000)$, etc. With respect to the number of its functional urban regions, Bulgaria does not differ from the other Central and East European countries in transition, where the number of big cities is much smaller than the one in the one in West European countries.

Sofia, Plovdiv, Varna and Burgas are the biggest cities in Bulgaria. In comparison with the inter-census period between 1992 and 2001, there was a change in the dynamics of the population size during the last decade, which witnessed a population increase in three of the seven large cities (Sofia, Varna and Burgas) (Table 1).

Manufacturing activities, services, education, science and cultural life are concentrated in large cities. The latter with their vicinity demonstrate a better general development level. "Large cities are and will continue to evolve as powerful centres with diverse regional functions: university education, science, $R \& D$ activities, manufacture, health care, business, commerce and banking, tourism, culture and spiritual life" (Operativna programa..., 2007, p. 48). Some of these cities form the biggest agglomerations in Bulgaria - Sofia, Plovdiv, Varna, Burgas, Pleven (Fig. 5). Owing to the specific parameters and functions of the biggest agglomeration in the country, the agglomeration of Sofia, has the greatest contribution to the formation of the state polycentric spatial structure in the context of

\footnotetext{
2 a one-day business trip according to ESPON 2013 means to have at least 6 hours available at the destination between leaving home after 5 a.m. and coming back home before 11 p.m. on the same day. The transport modes considered are rail, air or a combination of rail and air, based on actual timetables.
} 
the European conceptions. The agglomeration of Sofia is remarkable for its best developed material and technical facilities, diverse economic structure, completed technical and social infrastructure, etc. It produces the biggest share of the GDP in the country. The highest share of the direct foreign investments are oriented to the district of Sofia capital city - it received 60.8 per cent of the direct foreign investments in the country (2007, with accumulation) (Ilieva, 2006).

Table 1 Population dynamics of Bulgarian cities*

\begin{tabular}{|l|c|c|c|c|c|c|c|c|}
\hline & 1946 & 1956 & 1965 & 1975 & 1985 & 1992 & 2001 & 2011 \\
\hline Sofia & 473,3 & 652,1 & 825,5 & 990,3 & 1120,9 & 1114,9 & 1091,8 & 1204,7 \\
\hline Plovdiv & 128,6 & 164,9 & 229,0 & 299,6 & 342,0 & 341,1 & 338,2 & 338,2 \\
\hline Varna & 80,3 & 123,8 & 184,7 & 252,5 & 302,8 & 308,4 & 312,9 & 334,9 \\
\hline Burgas & 51,3 & 79,1 & 117,5 & 162,8 & 193,7 & 195,7 & 192,4 & 200,3 \\
\hline Ruse & 57,8 & 88,4 & 128,9 & 159,6 & 185,4 & 170,0 & 161,5 & 149,6 \\
\hline Stara Zagora & 38,3 & 56,2 & 88,6 & 122,3 & 150,3 & 150,5 & 143,4 & 138,3 \\
\hline Pleven & 39,1 & 57,6 & 78,7 & 107,6 & 129,7 & 130,8 & 121,9 & 107,0 \\
\hline Sliven & 35,3 & 47,3 & 69,9 & 90,2 & 102,1 & 106,2 & 100,4 & 91,6 \\
\hline Dobrich & 32,7 & 44,0 & 56,6 & 88,2 & 109,1 & 104,5 & 100,0 & 91,0 \\
\hline
\end{tabular}

* The cities of Sliven and Dobrich lost part of their population and passed to the group of medium-sized towns after 2001

Data source: National Statistical Institute

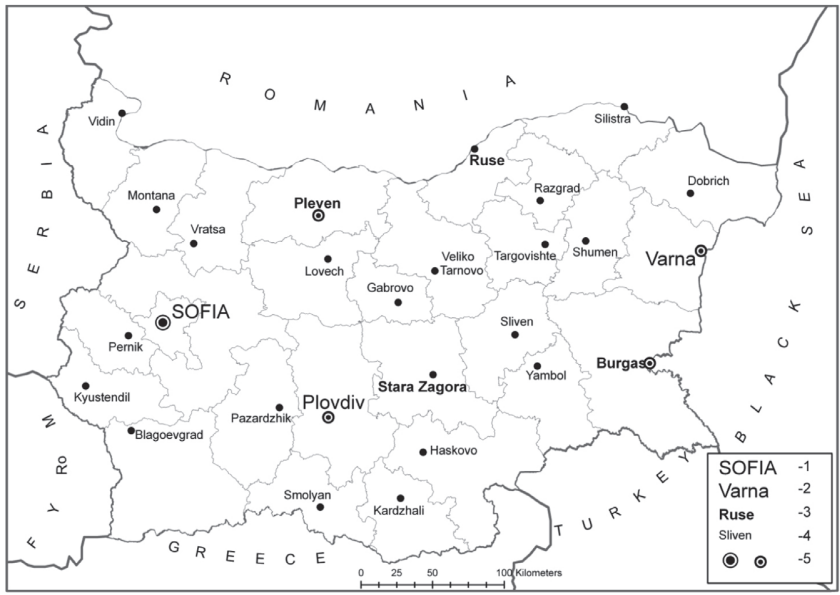

Fig. 5. District centres in Bulgaria (NUTS3 level)

1 - a city of over 1 million inhabitants|; 2 - a city with 200000 - 400000 inhabitants.; 3 - a city with 100000 - 200000 inhabitants.; 4 - medium-sized towns; 5 - cities - cores of agglomerations.

The role of the capital cities in regional development, where the most important elements of market economy are concentrated, is observed by Horvath (2009) in almost all countries of Central and Eastern Europe. According to him, this adverse and continuous territorial concentration must be changed. Fassmann (2000), Enyedi (2005), Tarkowski (2008), Horvath (2009) and some other authors emphasize the growing role of the capital, metropolitan and big cities in different countries. 
The development of the agglomerations of Sofia-capital, Plovdiv, Varna and Burgas has a positive influence on the development of the respective districts. These districts contribute with the highest share to the national GDP. The changes in GDP of the districts, occupying the first three and the last three positions ${ }^{3}$ in their ranking imply that the territorial disparities between them, deepen (Table 2). The share of the first three districts markedly grows (by 11.7 points, 1999-2007) whereas the share of the most underdeveloped districts decreases, although insignificantly. Slight changes have taken place in the composition of these groups.

Table 2 Share from the GDP value In Bulgaria

\begin{tabular}{|l|l|c|l|c|}
\hline \multirow{2}{*}{ Year } & \multicolumn{2}{|l|}{ The first three units in the districts rank } & \multicolumn{2}{l|}{ The last three units in the districts rank } \\
\cline { 2 - 5 } & Districts (NUTS3) & $\%$ & Districts (NUTS3): & $\%$ \\
\hline 1999 & Sofia-capital, Plovdiv, Burgas & 38.70 & Vidin, Smolyan, Silistra & 3.88 \\
\hline 2006 & Sofia-capital, Plovdiv, Varna & 47.40 & Vidin, Silistra, Yambol & 3.05 \\
\hline 2007 & Sofia-capital, Plovdiv, Varna & 50.39 & Yambol, Filistra, Vidin & 2.81 \\
\hline
\end{tabular}

Source: author's calculations, based on data from the National Statistical Institute

Sofia-capital, Varna and Burgas districts have achieved the best results in socio-economic transformation as revealed by the investigation of the territorial differences of transformation process in Bulgaria's 28 districts (NUTS3) on the basis of the calculated values of integral indicator ${ }^{4}$ (Ilieva, 2011).

The highest value of the integral indicator is recorded in the capital city of Sofia. Similar is the place of Budapest in comparison with other territorial units in Hungary. Aaccording to Enyedi (2005, p. 19) ,the most significant regional change in the economic performance has been the outstanding success of the Budapest Metropolitan Region, producing a growing gap between the capital city and the rest of the country". The current situation, conditions and prospects for future developments give grounds to assume that the differences between the capital city of Sofia and other districts will grow in the coming years.

Bulgaria's districts Varna and Bourgas come second after Sofia with significantly lower integral indicators. The value of their integral indicators differs considerably from calculated values of other areas. Against the background of the other areas in Bulgaria, Sofia-capital, Varna and Burgas districts can be conditionally defined as transformation's winners. Of course, it goes without saying that in comparison with NUTS3 in the EU configuration, even the capital city of Sofia is among the EU underdeveloped territorial units of that type.

According to Fassmann (1997), one of the regional consequences of the transformation measures is the increased importance of urban centres as growth poles of the national economy. The largest agglomerations in Bulgaria (those of Sofia, Plovdiv, Varna, Burgas) are formed in areas, characterized in this study by a high degree of socio-economic transformation (Fig. 6). Being economically better developed, they are in a favourable situation, "have experienced more easily the difficulties of restructuring and have been given better chances to attract investors, including foreign ones"

\footnotetext{
$310 \%$ of the number of analyzed territorial units (28) are used as a criterion in the table

4 The value of the integral indicator for each NUTS3 is obtained as a result of summing up the standardized values of the chosen 15 indicators
} 
(Parysek, 1998, p.40). Of the other big cities in Bulgaria (Rousse, Stara Zagora, Pleven) only Pleven is a core of an urban agglomeration (Iliev, 1995).

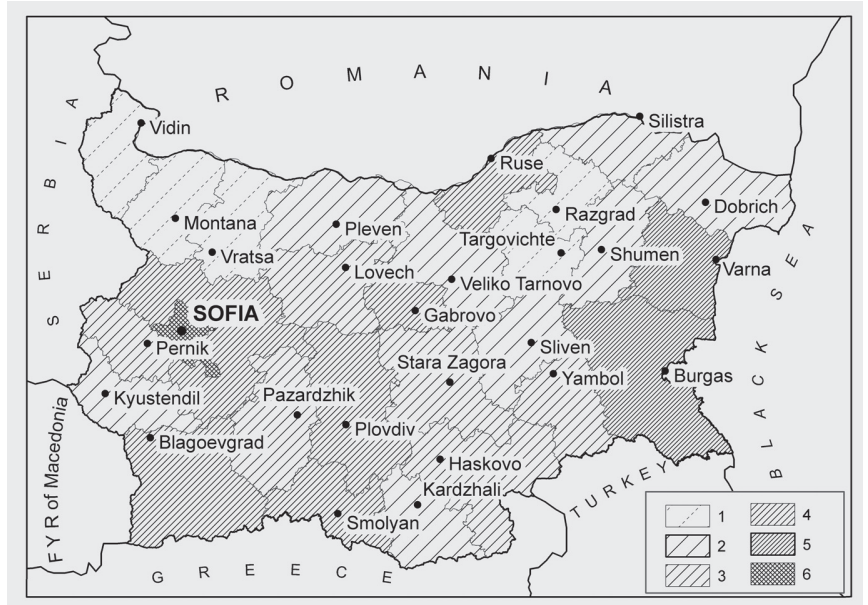

Fig. 6. Degree of socio-economic transformation, currently achieved

Value of integral indicator: 1 - from -10.9 to $-5.1 ; 2$ - from -5 to $-1.1 ; 3$ - from -1 to $1 ; 4$ - from 1.1 to 5 ; 5 - from 5.1 to $10 ; 6$ - over 28 .

Source: author's calculations, based on data from the National Statistical Institute

The First ESPON report (2010) underlies that "disparities in GDP per capita between the urban areas and their rural hinterland changed between 1995 and 2004. The functional regions in the eastern parts of the ESPON space show a marked increase of disparities" (p. 42). "It appears that the change of disparities in Eastern Europe is linked to the overall economic development of the regions. Strong economic growth in the cities has created opportunities which rural areas that are often still very agricultural cannot match. Growing disparities are the result. However, different phases in urbanisation processes may also play a role" (First ESPON..., p. 43). This research shows that, the disparity levels between Sofia and Varna metropolises and the surrounding region on NUTS 3 level (1995-2004) increase. The scale and trend of change in GDP per capita ratio during this period for Sofia is similar to that in Warsaw, Budapest, Prage, Bucarest, and for Varna - to those in NUTS3 with centres Bratislava, Gdansk and Dresden. .

The analysis indicates that the disparities between regions and districts in Bulgaria are also increasing in terms of the number and structure of population. The dominance of the large cities in different regions (NUTS2) in the country is growing in comparison with the previous periods. Relations between the population of the biggest city and the second urban settlement in the regions now vary from 1.45 (South-East region) to 15.02 (South-West region) (Table 3).

The growing importance of the Bulgarian urban settlements and agglomerations in the regional development underlies the regional policy, which has been implemented for the past two decades. "The uneven distribution of large cities becomes a factor for inter-regional and especially intraregional differences, which are more typical of the country and create challenges for the domestic (national) regional development policy" (Nationalna Strategia..., 2005, p. 49). The economic and demographic potential of Sofia and the other cities turn them into major dynamic regional centres 
with highly diverse national and regional functions. Besides, the development of the medium-sized towns has to be promoted by an efficient policy (Operativna Programa..., 2007).

Table 3 Dominance of the largest cities in regional settlement systems

\begin{tabular}{|c|c|c|c|c|c|}
\hline \multirow[t]{2}{*}{ Regions } & \multirow[t]{2}{*}{ Biggest city } & $\begin{array}{c}\text { Population of } \\
\text { the biggest city } \\
(1.03 .2011)\end{array}$ & $\begin{array}{c}\text { Share of the } \\
\text { biggest city's } \\
\text { population from } \\
\text { region } \\
\text { population }\end{array}$ & \multirow[t]{2}{*}{$\begin{array}{l}\text { Relation between } \\
\text { population of the } \\
\text { biggest city and } \\
\text { the second urban } \\
\text { settlement }\end{array}$} & \multirow[t]{2}{*}{$\begin{array}{l}\text { Name of the } \\
\text { second urban } \\
\text { settlement }\end{array}$} \\
\hline & & Thous. pers. & $\%$ & & \\
\hline North-West & Pleven & 107 & 12,63 & 1,76 & Vraca \\
\hline North Central & Ruse & 149,6 & 17,37 & 2,17 & Veliko Turnovo \\
\hline North-East & Varna & 334,9 & 34,66 & 3,68 & Dobrich \\
\hline South-East & Burgas & 200,3 & 18,58 & 1,45 & Stara Zagora \\
\hline South Central & Plovdiv & 338,2 & 22,86 & 4,43 & Haskovo \\
\hline South-West & Sofia & 1204,7 & 56,48 & 15,02 & Pernik \\
\hline BULGARIA & Sofia & 1204,7 & 16,36 & 3,56 & Plovdiv \\
\hline
\end{tabular}

Source: author's calculations, based on 2011 census data

Therefore thirty six agglomeration areas are identified in the country, being poles of growth in the national economy. The core of these areas are towns with a population of over 20000 people (except for the town of Panagiurishte whose population is below this limit) (Table 4). These agglomeration areas embrace about $1 / 3$ of the municipalities in Bulgaria. It means that 75 per cent of the country's population lives in them. The present-day national territorial-urban model identifies 3 hierarchical levels of city-centres and their surrounding agglomeration areas: capital city with its agglomeration, other cities of over 100 thousand inhabitants - Plovdiv, Varna, Burgas, Ruse, Pleven, Stara Zagora with their surrounding agglomeration areas and towns (incl. medium-sized towns and towns of over 20 thousand inhabitants) (Table 4, Fig. 7). The development of intra-regional cooperation between the core centres and their zones of influence is expected to enhance the development of the whole agglomeration area and thus to diminish somehow the intra-regional differences by expanding the economically more active territory and by facilitating the growth rates through relevant interventions.

Table 4 Agglomeration areas in Bulgaria

\begin{tabular}{|l|c|c|}
\hline $\begin{array}{c}\text { Number of inhabitants } \\
\text { of city / town }\end{array}$ & Number of agglomeration areas & $\begin{array}{c}\text { Number of cities/towns in Bulgaria } \\
\text { in corresponding category }\end{array}$ \\
\hline Capital city (over 1 million) & 1 & 1 \\
\hline Cities of over 100000 & 6 & 6 \\
\hline Towns $20000-100000$ & $29^{*}$ & $37^{* *}$ \\
\hline
\end{tabular}

* - including 1 town of less than 20000 ;** - without 1 town of over 50 000.(Asenovgrad), which is included in Plovdiv functional area and 8 towns (20000-50000 inhabitants), included in the agglomeration areas of other cities/towns in Blagoevgrad, Burgas, Gabrovo, Haskovo, Lovech, Sliven, Veliko Tarnovo districts.

Source: data from the Operational Program "Regional Development" and the National Statistical Institute 


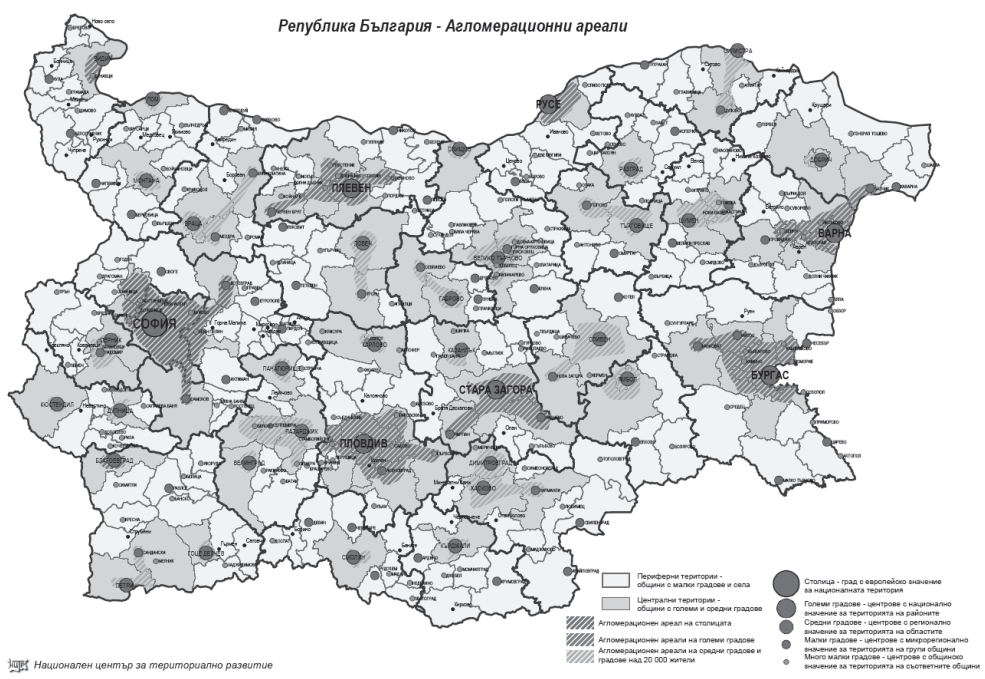

Fig. 7. Agglomeration areas in Bulgaria

Source: Operational Program "Regional Development”, 2007

The Operational Program "Regional Development" (2007) emphasizes that the long distance from the city centres has favoured the formation of peripheral regions not only in the border areas but also in the inner margins of the Danube Plain (North Bulgaria), the Upper Thracian Lowland (south part of the country), etc. By contrast with Poland ${ }^{5}$ and some other countries, in Bulgaria there are no geographical investigations of the existing transport links and accessibility to the big cities and medium-sized towns, of the links between large companies, of the social relations, etc. Taking into account the expert assessment, it can be concluded that alongside with the railway transport, which in the other countries is fundamental for the connection of the metropolises, the road transport in Bulgaria seems to be very important for the transport links between the big cities and the centres of the functional urban areas. In some cases (e.g. Varna, Burgas) the availability of airports and the maintenance of home airlines are also significant factors. Because of the long distances between the large cities, their distribution in the form of two semi-ellipses (Sofia-Pleven-Ruse-Varna, SofiaPlovdiv-Stara Zagora-Burgas), the location of some of them in border areas (Ruse, Varna, Burgas), the configuration of the railway and road network, etc., the time needed for business and other trips is highly different. Due to the daily flights to/from Sofia, the time to cover the distance to Varna and Burgas (about 400-500 km) is less than that needed to reach other big cities, 150-200 km away from Sofia. According to ESPON FOCI 2010 research, the potential multimodal accessibility ${ }^{6}$ only for Sofia district is higher as compared to the ESPON average. Similar is the situation with the remaining countries from Central and Eastern Europe, where only the capital-city areas are notable for their higher values of the indicator and the other parts of the countries the potential multimodal accessibility is lower in comparison with the ESPON average.

5 Komornicki, T., P. Siłka (Eds.) Functional linkages between polish metropolises. Warszawa, 2011

6 Potential accessibility describes how easily people in one region can reach people located in other regions. Within the accessibility model used by ESPON, potential accessibility is based on two elements: (a) population in NUTS 3 regions, and (b) effort in time to reach them (ESPON.., 2010, pp.40). 
The regional policy of Bulgaria defines the towns as the driving force of development, accentuates the urban dimension of cohesion policy, emphasizes the importance of the territorial planning strategies, and encourages the relationships between urban and rural regions which are currently underdeveloped. "The thriving cities/towns, closely connected with their less populated countryside, in the long run will cause beneficial changes for regions, now experiencing a serious decline and depopulation. Thus in practice, the problem of intra-regional differences will be solved. [...]. On the other hand, the better connection of the cities/towns with their adjacent area in terms of access not only to the transport system, but also to information and communication networks, services and efficient energy resources, will result in more favourable conditions for development in these regions.” (Operativna Programa, 2007, p. 94-95).

\section{REFERENCES}

Enyedi G., 2005, Processes of regional development in Post-socialist Hangary, in Barta, G., E.G. Fekete, I.K. Szorenyjne, J. Timar. Hungarian Spaces and places: patterns of transition, Pecs.

ESPON 1.1.1., 2004, Potentials for policentric development in Europe. Final report.

ESPON 2013 PROGRAMME. European observation network on territorial development and cohesion. European Commission, November 2007. www.mrrb.government.bg/20.10.2011

Fassmann H., 1997, Regionale Transformationsforschung. Theoretische Begrundung und empirische Beispiele, in Regionale Transformationnsprozesse in Europa. Beitrage zur Regionalen Geographie, 44, Leipzig.

Fassmann H., 2000, Regions in upheaval. Conceptual framework and empirical findings of the regional transformation research, in G. Horvath (ed.), Regions and cities in the global world, Pecs.

First ESPON 2013 synthesis report, ESPON results by summer 2010. Luxembourg, October, 2010, www.espon.eu/27.10.2011

Horvath G., 2009, Cohesion Deficiencies in Eastern and Central Europe - Inequalities of Regional Research Area, DISCUSSION PAPERS, 72, Centre for Regional Studies of Hungarian Academy of Sciences, Pecs.

Iliev I., 1995, Formirane na Plevenskata aglomeracia i antropogenio transformirane na nejnata terytoria. [Formation of Pleven agglomeration and anthropogenic transformation of its territory], Unpublished Ph.D. thesis, Sofia University (in Bulgarian).

Ilieva M., 2006, Sofia in the transformation period 1990-2004: trends and prospects, in T. Komornicki, K. Czapiewski (eds.), Core and peripheral regions in Central and Eastern Europe. Europa XXI, 14:95-112.

Ilieva M., 2011, Territorial differences in transformation processes in Bulgaria, Journal of Urban and Regional Analysis, vol. III, 1:13-25.

Komornicki T., Siłka P. (Eds.), 2011, Functional linkages between polish metropolises, Polish Academy of Sciences, Committee for Spatial Economy and Regional Planning, Warszawa.

Naredba No 5 ot 17.05 .1995 za pravila i normi po teritorialno i selishtno ustrojstvo [Regulation \#5 from 17.05.1995 for regulations and norms of territorial and settlements organization]. Darzhaven vestnik, No 48/26.05.1995

Nationalna strategia za regionalno razvitie na Republika Bulgaria za perioda 2005-2015 [National Regional Development Strategy of the Republic of Bulgaria for the period 2005-2015]. www. mrrb.government.bg 
Okonchatelni rezultati ot Prebroyavane 2011. - www.nsi.bg/27.10.2011

Operativna programa „Regionalno razvitie” 2007-2013 [Operational Program “Regional Development” 2007-2013), Ministry of Regional Development and Public Works (2007]. www.mrrb. government.bg/5.10.2011

Parysek J., 1998, The spatial dimension of the process of socioeconomic transformation (in the first 6 years), in Domański, R. (ed.) Emerging spatial and regional structures of an economy in transition, PWN, Warszawa.

Tarkowski M., 2008, Centra i peryferie rozwoju spoleczno-gospodarczego Polski w okresie transformacji ustrojowej [Center and periphery of social-economic development In Poland during the system transformation period], Gdynia-Pelplin (in Polish). 
http://rcin.org.pl 